\title{
JUURNAL.RU
}

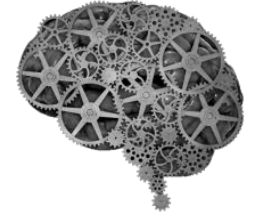

COMPANY GROUP "INTELLEKT"

Патлатый К.Э., Ноликов М.С., Дядьков В.А., Червяков А.В., Костин К.Б., Горшков Н.В., Пичхидзе С.Я.

СГТУ имени Ю.А. Гагарина

Саратов, Россия

doi: 10.18411/lj2016-8-1-10

idsp 000001:lj2016-17-1-10

\section{Модернизация конструкции локтевого эндопротеза}

Для лечения повреждений локтевого сустава обычно применяются известные технологии остеосинтеза суставных фрагментов костей и коррекции внутренних структур сустава [1...3] с использованием фосфатной биокерамики.

Цель работы: усовершенствование конструкции локтевого эндопротеза в интересах увеличения времени его эксплуатации путем нанесения цинксодержащего гидроксиапатитового (Zn-ГА) покрытия на локтевую и плечевую ножки.

Методика эксперимента. Синтез Zn-ГА проводили из растворов при $\mathrm{pH}$ 9...11 по аналогии [4...6] при стехиометрии:

$(10-\mathrm{x}) \mathrm{Ca} 2++\mathrm{xZn} 2++6 \mathrm{PO} 43-+2 \mathrm{OH}-\rightarrow \mathrm{Ca} 10-\mathrm{xZnx}(\mathrm{PO} 4) 6(\mathrm{OH}) 2,0<\mathrm{x}<1,0$
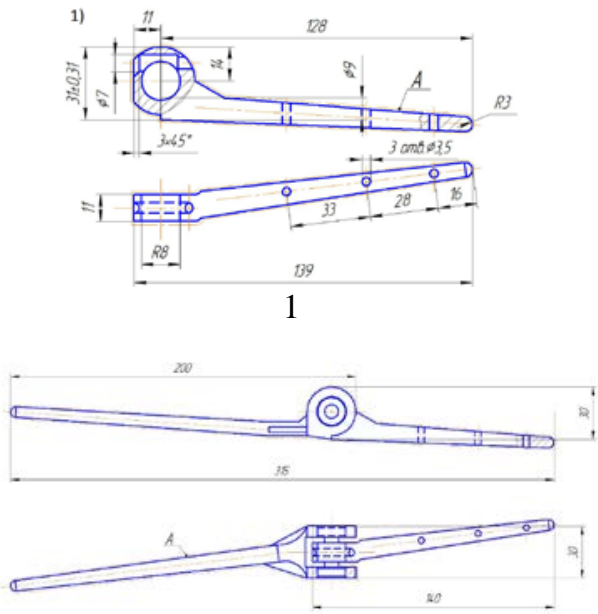

3
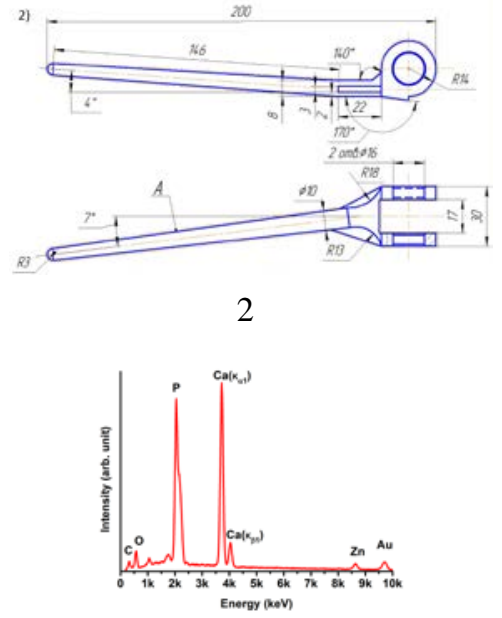

4

Рис.1 Локтевой эндопротез с нанесенным покрытием А ( $\mathrm{Zn}-\Gamma A): 1)$ локтевая ножка,

2) плечевая ножка, 3) сборочный чертеж, 4) ЭДРА Zn-ГA 
Подтверждение состава Zn-ГА проводилось методом РЭМ/ЭДРА на дифрактометре ARL X'TRA “Thermo Fisher Scientific” и растровом электронном микроскопе Aspex Explorer (США) при ускоряющем напряжении электронного пучка $20 \mathrm{kV}$ с приставкой для энергодисперсионного рентгеновского анализа. Для снятия статического заряда на поверхность образцов наносилась тонкая пленка $\mathrm{Au}$ методом магнетронного напыления. Нанесение биоактивного антимикробного Zn-ГА проводили методом микродугового оксидирования.

Выводы: усовершенствована конструкция эндопротеза плечевого сустава: модернизировано покрытие локтевой и плечевой ножек, увеличен срок эксплуатации протеза. 


\section{Литература:}

1. Слободской А.Б., Бадак И.С., Воронин И.В. и др. Эндопротезирование при лечении травм и заболеваний локтевого сустава //Остеосинтез и эндопротезирование: Материалы Междунар. Пироговской науч.-практ. конф. — M., 2008. - c.164.

2. Эндопротезирование суставов. - 2010. [Электронный ресурс]. URL: http://www.orthoscheb.com/Page.aspx?page=./28209/28223/29160 （дата обращения 20.06.2013).

3. Патент РФ № 95111313, A61F2/38. Эндопротез локтевого сустава / Архипов С.В. - №95111313/14. заявл. 30.06.1995, опубл. 10.07.1997, Бюл. №26. - 5с.

4. Смоленко Д.М., Горбачев И.А., Костин К.Б., Маркелова О.А., Дударева О.А., Лясникова А.В., Пичхидзе С.Я. Идентификация цинксодержащего ТКФ. Тенденции науки и образования в современном мире. Самара: Л-Журнал, 2016. № 12-2. C. 22-23.

5. Лясникова А.В., Лясников В.Н., Маркелова О.А., Дударева О.А., Пичхидзе С.Я., Гришина И.П. Исследование свойств сереброзамещенного гидроксиапатита и биокомпозиционных наноструктурированных покрытий на его основе. Медицинская техника, №5, 2015. - с. 38-40.

6. Lyasnikova A. V., Pichkhidze S. Ya., Dudareva O. A., Markelova O. A. Properties of magnesium-substituted hydroxyapatite and the plasma coatings based on it. Technical Physics, V. 60, Issue 11, 2015. - p. 1725-1728. 